\title{
Influence of Tillage Systems on the Degree of Weeding on Agricultural Crops at ARDS Turda
}

\author{
Alina ŞIMON*, Felicia CHEŢAN, Cornel CHEŢAN, Marius BĂRDAȘ \\ Agricultural Research-Development Station Turda, 25 Agricultirii St., Turda, România \\ *corresponding author: maralys84@yahoo.com
}

Bulletin UASVM series Agriculture 76(2) / 2019

Print ISSN 1843-5246; Electronic ISSN 1843-5386

DOI:10.15835/buasvmcn-agr: 2018.0029

\begin{abstract}
Plants of spontaneous flora are in constant competition with culture plants for water, nutrients and other vegetation factors. The degree of weeding was determined in 2014-2016, at four crops - winter wheat, maize, soybeans and peas, cultivated in conventional tillage system and conservation tillage. Temperatures and precipitations registered on the vegetation period in three year had a high influence on the number of weeds found in agricultural crops, so in 2015 there was a smaller number of weeds than in 2014 respectively 2016. Of the species determined in this period is noted for annual dicotyledonous (most of them Chenopodium sp., Veronica sp. and Xanthium strumarium), and among the species of monocotyledonous species Echinochloa sp. and Setaria sp. which are found in all four cultures. In the case of the application of conservative tillage systems there is an increase in the number of weeds compared to the conventional tillage system. The average yields obtained by maize, soybean and peas at application of conservative tillage systems are close to the classical tillage system, the winter wheat yield was higher in the no tillage system than in the classical tillage system.
\end{abstract}

Keywords: tillage systems, weeds control, climatic conditions, agricultural crops

\section{Introduction}

In the least years, agriculture has undergone important changes in agricultural crop technology through the implementation of conservative tillage systems. The new environmental conditions created by the application of conservative tillage systems lead to changes in the weed spectrum, the number of perennial being increasing (Şimon and Chețan, 2017).

Plants of spontaneous flora are in constant competition with the crop plants from the emergence to the harvest (Patel et al., 2003) for water, nutrients and other vegetation factors, depreciating the quantitative and qualitative production of crops. The most significant sources of weed infestation of crops include weeds seeds deposited in soil and agricultural practices applied (Gruber and Claupein, 2009). Following research by Chețan et al. (2016), participation of weed species to the degree of weeds in the corn crop results that the highest percentage was held by the dicotyledonous annual weeds was $51 \%$ in classical tillage system and $48 \%$ in minimum tillage system. Tillage modifications have a significant effect on weed emergence and weed seed distribution in the soil profile (Torresen et al., 2003). Tillage, or the absence of tillage, can affect weed, pest and diseases population and determining the formation of specific agrocenoses (Woźniak and Soroka, 2015). From an inventory of existing weeds, effectuated by Chețan and collaborators in 2015, in experiences with minimum tillage results in a total of 18 species of which the most common being Xanthium strumarium annual dicots and Hibiscus trionum, followed by annual monocots and Setaria glauca, Echinochloa crus-galli.

The abundant rainfall in July, August and September correlated with a warm heat regime 
favors the late infestation of autumn crops, and when harvesting crops the degree of weeding is very high and the stock of weed seeds that accumulates in the soil is continually growth (Bogdan, 2005).

For the best possible control of weeds in agricultural crops it is very important to know the weed spectrum and apply herbicides specific to the existing weed category because a small number of weeds or ephemera species are not a very big problem for the crop plants and the cost of combating them is not economically justified (Bogdan, 2005).

\section{Materials and methods}

The purpose of this study was to determine the existing weed species, following the application of the conservative tillage system to the main crops of ARDS Turda, in order to choose the optimal method of reducing the number of weed species.

The experiment was conducted in the period 2014-2016 at the Agricultural ResearchDevelopment Station Turda (ARDS), on soil type vertic faeozem, $\mathrm{pH}$ neutral (6.96), with ClayLoam texture, medium humus content (3.56\%), good supply in mobile phosphorus and potassium.

The degree of weeding was determined at four crop plants (winter wheat, maize, soybean and peas) cultivated in conventional tillage system and unconventional tillage systems (winter wheat cultivated in classical tillage system and no tillage system and maize, soybean and peas cultivated in the classical tillage system and the minimum tillage system, chisel variant).

The conventional tillage system included ploughing at $25 \mathrm{~cm}$ depth after harvest of the previous crop and processing with rotary harrow before sowing, the minimum tillage system involved the use of a chisel at $30 \mathrm{~cm}$ depth after harvest of the previous crop and processing with rotary harrow before sowing and the no tillage system included direct sowing.

Immediately after sowing for maize, soybean and peas it was made one treatment with Gliphosate (glifosat 360g/l) (4 l/ha). Monocotyledonous and dicotyledonous weeds control was made, after emergence of the crop, with herbicides Pulsar (imazamox $40 \mathrm{~g} / \mathrm{l})$ (1,0 l/ha) and Agil (propaquizafop) $(1,0 \mathrm{l} / \mathrm{ha})$ in a weeds rosette phenophase for peas and soybean, with herbicides Ceredin (300 g/l acid 2.4-D + $100 \mathrm{~g} / \mathrm{l}$ dicamba)
(1 l/ha) for maize and with herbicides Sekator Progres OD (amidosulfuron $100 \mathrm{~g} / \mathrm{l}+$ iodosulfuronmetil-Na $25 \mathrm{~g} / \mathrm{l}+$ mefenpyr dietil $250 \mathrm{~g} / \mathrm{l}) \quad(0,15 \mathrm{l} /$ ha) and DMA 6 (acid 2.4D $660 \mathrm{~g} / \mathrm{l})(0,6 \mathrm{l} / \mathrm{ha})$ for winter wheat.

The surface on which the determinations were made was 1 ha, on this surface were made 10 determinations with the help of the metric frame, for each crop separately, the obtained data being calculated as an average of the surface, determination of the weed flora it was made with metric frame (with dimension: $0.5 \times 0,5$ $\mathrm{m})$, by numerical method, before treatment with herbicides.

The yield results obtained were statistically processed according to the method of analyzing the variant and establishing the lowest significant differences, LSD (5\%, $1 \%$ and $0.1 \%$ ) (ANOVA, 2015).

Climate conditions are a determinant of agricultural yield, and the analysis of the evolution of climatic factors is justified in the current context of climate change, which is increasingly visible both globally and in our country. The climatic conditions of the years 2014-2016 are presented according to the Turda Meteor Station. Over the past 59 years, the annual average temperature recorded was $9,1^{\circ} \mathrm{C}$ (Tab.1) and the annual precipitation amount was $513.6 \mathrm{~mm}$ (Tab. 2). The average temperatures recorded during the crop growing months varied in the three years but were higher than the average for 59 years with $2^{\circ} \mathrm{C}$ in 2014 being considered the most warmly year at the least 59 years, with $1,5^{\circ} \mathrm{C}$ in 2015 being considered a warm year and $0,9^{\circ} \mathrm{C}$ in 2016, a year considered warmly. In 2016, the temperature values recorded in the soybean crop growing months ranged from multi-year averages with a deviation of $-0,7^{\circ} \mathrm{C}$ in May, with a cool spring up to $+2^{\circ} \mathrm{C}$ in June, characterized as a warm moon, in the other months the recorded temperatures were close to normal.

The year 2014 was a good year for all crops because in the summer months there was rain with a large amount of water falling, the year being considered excessively rainy. The amount of precipitation recorded in the first half of 2015 was below the monthly average of the 59 years, the spring months of 2015 were drought, and in June although it was a very rainy month in the first decade, only $0.6 \mathrm{l} / \mathrm{m}^{2}$, following very dry July and rainy August, soybean suffered during this period 
Table 1. Average air temperatures $\left({ }^{\circ} \mathrm{C}\right)$, Turda 2015-2016

\begin{tabular}{ccccccccccccc}
\hline \multirow{2}{*}{ Monthly average } & \multicolumn{10}{c}{2014} \\
\cline { 2 - 12 } & Ian. & Feb. & Mar. & Apr. & May & Jun. & Jul. & Aug. & Sep. & Oct. & Nov. & Dec. \\
\cline { 2 - 12 } & 0.5 & 3.8 & 8.8 & 11.4 & 15.1 & 18.5 & 20.4 & 19.9 & 16.6 & 10.8 & 5.7 & 1.3 \\
\hline Average 59 years & -3.4 & -0.8 & 4.5 & 9.9 & 15.0 & 17.8 & 19.7 & 19.3 & 15.0 & 9.5 & 3.9 & -1.4 \\
\hline Deviation & +3.9 & +4.6 & +4.3 & +1.5 & +0.1 & +0.7 & +0.7 & +0.6 & +1.6 & +1.3 & +1.8 & +2.7 \\
\hline \multirow{2}{*}{ Monthly average } & Ian. & Feb. & Mar. & Apr. & May & Jun. & Jul. & Aug. & Sep. & Oct. & Nov. & Dec. \\
\cline { 2 - 13 }$y$ & -0.7 & 0.0 & 5.5 & 9.6 & 15.8 & 19.4 & 22.3 & 21.9 & 17.3 & 9.7 & 6.1 & 0.7 \\
\hline Average 59 years & -3.4 & -0.8 & 4.5 & 9.9 & 15.0 & 17.8 & 19.7 & 19.3 & 15.0 & 9.5 & 3.9 & -1.4 \\
\hline Deviation & +2.7 & +0.8 & +1.1 & -0.3 & +0.8 & +1.6 & +2.6 & +2.6 & +2.3 & +0.2 & +2.2 & +2.3 \\
\hline \multirow{2}{*}{ Monthly average } & Ian. & Feb. & Mar. & Apr. & May & Jun. & Jul. & Aug. & Sep. & Oct. & Nov. & Dec. \\
\hline & -2.8 & 4.6 & 5.9 & 12.4 & 14.3 & 19.8 & 20.5 & 19.6 & 17.1 & 8.3 & 2.9 & -2.7 \\
\hline Average 59 years & -3.4 & -0.8 & 4.5 & 9.9 & 15.0 & 17.8 & 19.7 & 19.3 & 15.0 & 9.5 & 3.9 & -1.4 \\
\hline Deviation & +0.6 & +5.4 & +1.4 & +2.5 & -0.7 & +2.0 & +0.8 & +0.3 & +2.1 & -1.2 & -1.0 & -1.3 \\
\hline
\end{tabular}

Source: Turda Meteor Station, longitude: $23^{\circ} 47$ '; latitude $46^{0} 35$ '; altitude $427 \mathrm{~m}$

Table 2. Recorded precipitation (mm), Turda 2015-2016

\begin{tabular}{|c|c|c|c|c|c|c|c|c|c|c|c|c|}
\hline \multirow{3}{*}{$\begin{array}{l}\text { Month. } \\
\text { amount }\end{array}$} & \multicolumn{12}{|c|}{2014} \\
\hline & Ian. & Feb. & Mar. & Apr. & May & Jun. & Jul. & Aug. & Sep. & Oct. & Nov. & Dec. \\
\hline & 51.6 & 15.5 & 23.1 & 72.0 & 66.2 & 48.4 & 144.4 & 83.8 & 48.4 & 67.4 & 34.2 & 86.6 \\
\hline Av. 59 years & 20.8 & 18.4 & 19.3 & 44.4 & 67.1 & 83.4 & 72.9 & 54.6 & 42.0 & 32.5 & 32.3 & 26.0 \\
\hline Deviat. & +30.8 & -2.9 & +3.8 & +27.6 & -0.9 & -35.0 & +71.5 & +28.9 & +6.4 & +34.9 & +1.9 & +60.6 \\
\hline \multicolumn{13}{|c|}{2015} \\
\hline \multirow{2}{*}{$\begin{array}{l}\text { Month. } \\
\text { amount }\end{array}$} & Ian. & Feb. & Mar. & Apr. & May & Jun. & Jul. & Aug. & Sep. & Oct. & Nov. & Dec. \\
\hline & 12.3 & 20.9 & 12.8 & 32.2 & 66.0 & 115.7 & 52.2 & 72.2 & 172.6 & 45.4 & 32.0 & 6.9 \\
\hline Av. 59 years & 20.8 & 18.4 & 19.3 & 44.4 & 67.1 & 83.4 & 72.9 & 54.6 & 42.0 & 32.5 & 32.3 & 26.0 \\
\hline Deviat. & -9.0 & +2.2 & -10.3 & -12.5 & -1.7 & +31.2 & -24.5 & +16.3 & +132.3 & +13.4 & +3.3 & -20.0 \\
\hline \multicolumn{13}{|c|}{2016} \\
\hline \multirow[t]{2}{*}{$\begin{array}{l}\text { Month. } \\
\text { amount }\end{array}$} & Ian. & Feb. & Mar. & Apr. & May & Jun. & Jul. & Aug. & Sep. & Oct. & Nov. & Dec. \\
\hline & 25.0 & 23.8 & 47.0 & 62.2 & 90.4 & 123.2 & 124.9 & 91.0 & 24.6 & 152.2 & 45.3 & 7.2 \\
\hline Av. 59 years & 20.8 & 18.4 & 19.3 & 44.4 & 67.1 & 83.4 & 72.9 & 54.6 & 42.0 & 32.5 & 32.3 & 26.0 \\
\hline Deviat. & +4.2 & +5.4 & +27.7 & +17.8 & +23.3 & +39.8 & +52.0 & +36.4 & -17.4 & +119.7 & +13 & -18.8 \\
\hline
\end{tabular}


due to the drought recorded during periods of vegetation when it needed acute water, which was specific to the summers of 2015 was the persistence of high temperatures up to on the heel threshold, over a long period of time.

In 2016, the sum of precipitations was higher than the average for 59 years, being considered an excessively rainy year, temperatures and precipitation were beneficial for soybean culture, and yields are the result of the interaction of optimum climatic conditions.

\section{Results and discussion}

In the winter wheat crop, in the period 20142016, 15 species of weeds were determined before the end of the twin, as can be seen in Tab. 3, the number of weeds $/ \mathrm{m}^{2}$ in the classical tillage system is higher than in the conservative tillage system, due to the lack of soil processing, the germination conditions of the weed seeds are not met in the case of direct sowing.
The largest share was the Xantium strumarium, Chenopodium album, Echinochloa crus-galli, Polygonum convolvulus species, both in the classical system and in the conservative system (Tab. 3). Of the 15 species of weeds determined in the three years in winter wheat crops, only 9 species were found each year, most of them being in the annual dicotyledonous category.

Pea culture is very sensitive to degree of weeding in the early stages of development and reinfestation with weeds during the baking period, so production is largely conditioned by the degree of weeding extent of the culture.

Following the determinations made after the emergence of pea culture, 19 weed species (the largest of the four studied cultures) were identified in the two tillage systems in 20142016, out of which only 8 species were found every year. Most identified species were from the annual dicotyledonous category, the most important being Chenopodium album, Xantium strumarium and Polygonum convolvulus, very

Table 3. The number of weeds $/ \mathrm{m}^{2}$ emerged in the wheat culture, Turda 2014-2016

\begin{tabular}{|c|c|c|c|c|c|c|c|}
\hline \multirow{4}{*}{$\begin{array}{l}\mathrm{Nr} . \\
\text { crt. }\end{array}$} & \multirow{4}{*}{ Species } & \multicolumn{6}{|c|}{ Tillage system } \\
\hline & & \multicolumn{3}{|c|}{ Classical tillage } & \multicolumn{3}{|c|}{ No tillage } \\
\hline & & \multicolumn{6}{|c|}{ Year } \\
\hline & & 2014 & 2015 & 2016 & 2014 & 2015 & 2016 \\
\hline 1 & Agropyron repens* & 1 & 1 & - & 2 & - & 1 \\
\hline 2 & Amaranthus retroflexus & 1 & - & 1 & - & - & 1 \\
\hline 3 & Anagallis arvensis* & 1 & 1 & 1 & - & 1 & - \\
\hline 4 & Chenopodium album* & 6 & 5 & 7 & 5 & 4 & 4 \\
\hline 5 & Cirsium arvense* & - & 1 & 1 & 1 & - & - \\
\hline 6 & Echinochloa crus-galli* & 4 & 2 & 3 & 5 & 2 & 2 \\
\hline 7 & Hibiscus trionum & 2 & - & 1 & - & - & 4 \\
\hline 8 & Lathyrus tuberosus & - & 2 & - & - & 1 & 1 \\
\hline 9 & Polygonum convolvulus* & 1 & 1 & 2 & 2 & 1 & 1 \\
\hline 10 & Rubus caesius* & - & 1 & - & 1 & - & 1 \\
\hline 11 & Setaria glauca* & 5 & 1 & 2 & 3 & 2 & 4 \\
\hline 12 & Silene noctiflora & - & - & 2 & - & - & 1 \\
\hline 13 & Veronica persica & - & 1 & 2 & - & 2 & 2 \\
\hline 14 & Viola arvensis & - & 1 & 1 & - & - & 1 \\
\hline 15 & Xantium strumarium* & 6 & 4 & 10 & 5 & 7 & 5 \\
\hline & Total & 27 & 21 & 33 & 23 & 20 & 28 \\
\hline
\end{tabular}

*Weeds found in culture every year 
common species on the fields of the experimental field at SCDA Turda and very difficult to control, and among monocotyledons Setaria glauca and Echinochloa crus-galli, as shown in Tab. 4. The climatic conditions in 2015 made the number of weed species found in agricultural crops lower than in 2016, the year with the highest number of weeds per $\mathrm{m}^{2}$.

Soybean is a plant sensible to degree of weeding in the early stages of development but also to re-infestation throughout the growing season if sown at a great distance between rows, combating weeds in this crop with herbicides is very important and production is implanted in the sea as measured by the degree of culture saturation. According to Chețan et al. (2016) the degree of weeding springs dry soybean crop is higher, this is due to adaptability of weeds to harsh environmental conditions to plant crops.

In the 2014-2016 period, 17 species of monocotyledonous and dicotyledonous weeds were determined in the soybean culture, but only 10 species of these were found in the three years.

As can be seen from Table 5, in the classical tillage system a lower number of weed species was determined, most of them being of the dicotyledonous species, compared to the conservative tillage system, and the largest share was Chenopodium album, Xanthium strumarium, Polygonum convolvulus of dicotyledonous species and Echinochloa crus-galli, Setaria glauca of the monocotyledonous species.

Of the three years studied, in 2016 the largest number of weeds is observed, the climatic

Table 4. Number of weeds $/ \mathrm{m}^{2}$ after the emergence of pea culture, Turda 2014-2016

\begin{tabular}{|c|c|c|c|c|c|c|c|}
\hline \multirow{4}{*}{$\begin{array}{l}\text { Nr. } \\
\text { crt. }\end{array}$} & \multirow{4}{*}{ Species } & \multicolumn{6}{|c|}{ Tillage system } \\
\hline & & \multicolumn{3}{|c|}{ Classical tillage } & \multicolumn{3}{|c|}{ Minimum tillage } \\
\hline & & \multicolumn{6}{|c|}{ Year } \\
\hline & & 2014 & 2015 & 2016 & 2014 & 2015 & 2016 \\
\hline 1 & Agropyron repens* & 4 & 1 & - & 3 & - & 1 \\
\hline 2 & Amaranthus lividus & - & - & 3 & - & - & 1 \\
\hline 3 & Anagallis arvensis* & 1 & 1 & 1 & - & - & - \\
\hline 4 & Bromus secalinus & - & - & 1 & - & - & 2 \\
\hline 5 & Chenopodium album* & 6 & 5 & 5 & 3 & 7 & 6 \\
\hline 6 & Cirsium arvense* & - & 1 & 1 & 1 & - & - \\
\hline 7 & Echinochloa crus-galli & 4 & 2 & - & 5 & 1 & - \\
\hline 8 & Hibiscus trionum & - & - & - & - & - & 1 \\
\hline 9 & Lathyrus tuberosus & - & 2 & - & - & 1 & 1 \\
\hline 10 & Myosotis arvensis & - & - & - & - & 1 & - \\
\hline 11 & Polygonum convolvulus* & 1 & 1 & 2 & 3 & 2 & 1 \\
\hline 12 & Rubus caesius* & - & 1 & - & 1 & - & 1 \\
\hline 13 & Setaria glauca* & 5 & 1 & 2 & 5 & 2 & 1 \\
\hline 14 & Silene noctiflora & - & - & 2 & - & - & - \\
\hline 15 & Sinapis arvensis & - & - & - & 1 & - & - \\
\hline 16 & Sonchus asper & - & 1 & - & - & 1 & - \\
\hline 17 & Veronica persica & - & 1 & - & - & 1 & - \\
\hline 18 & Viola arvensis & - & 1 & - & - & - & - \\
\hline 19 & Xantium strumarium* & 2 & 4 & 10 & 6 & 8 & 12 \\
\hline & Total & 23 & 22 & 27 & 28 & 24 & 27 \\
\hline
\end{tabular}

*Weeds found in culture every year 
Table 5. Number of weeds $/ \mathrm{m}^{2}$ after the emergence of soybean culture, Turda 2014-2016

\begin{tabular}{|c|c|c|c|c|c|c|c|}
\hline \multirow{4}{*}{$\begin{array}{l}\text { Nr. } \\
\text { crt. }\end{array}$} & \multirow{4}{*}{ Species } & \multicolumn{6}{|c|}{ Tillage system } \\
\hline & & \multicolumn{3}{|c|}{ Classical tillage } & \multicolumn{3}{|c|}{ Minimum tillage } \\
\hline & & \multicolumn{6}{|c|}{ Year } \\
\hline & & 2014 & 2015 & 2016 & 2014 & 2015 & 2016 \\
\hline 1 & Amaranthus retroflexus & 1 & - & 3 & - & - & 1 \\
\hline 2 & Anagallis arvensis* & 1 & 1 & 1 & 1 & - & - \\
\hline 3 & Capsella bursa-pastoris & 1 & - & 2 & - & - & 1 \\
\hline 4 & Chenopodium album* & 6 & 5 & 5 & 3 & 3 & 3 \\
\hline 5 & Delphinium consolida & 1 & - & 1 & 1 & - & 2 \\
\hline 6 & Echinochloa crus-galli* & 4 & 2 & 2 & 5 & 3 & 4 \\
\hline 7 & Hibiscus trionum* & 1 & - & 4 & 2 & 1 & 6 \\
\hline 8 & Lathyrus tuberosus & - & 2 & - & - & 1 & 1 \\
\hline 9 & Polygonum aviculare & - & - & 1 & 1 & - & 1 \\
\hline 10 & Polygonum convolvulus* & 1 & 1 & 2 & 3 & 2 & 3 \\
\hline 11 & Rubus caesius* & - & 1 & - & 1 & 1 & 1 \\
\hline 12 & Setaria glauca* & 5 & 1 & 2 & 5 & 2 & 3 \\
\hline 13 & Silene noctiflora & - & - & 2 & 1 & - & 2 \\
\hline 14 & Sinapis arvensis & - & - & 1 & 1 & - & 1 \\
\hline 15 & Veronica persica* & - & 1 & 2 & 1 & 1 & 3 \\
\hline 16 & Viola arvensis* & - & 1 & 1 & 2 & 1 & 2 \\
\hline 17 & Xantium strumarium* & 4 & 4 & 10 & 6 & 5 & 12 \\
\hline & Total & 25 & 19 & 39 & 33 & 20 & 46 \\
\hline
\end{tabular}

*Weeds found in culture every year

conditions of the soybean crop growing season being one of the determinants of the emergence and development of weeds.

The maize crops from the central region of Transylvania suffer from great weed infestation that made us find the optimal strategies from management and economic point of view, to reduce weed encroachment degree under the damaging limit (Bogdan et al., 2007).

In corn crops, a total of 17 species of weeds were determined in 2014-2016, as can be seen in Tab. 6, of which only 9 species were recorded each year, most species being annual dicots.

In the case of the application of the conservative tillage system, the number of weeds determined was higher than the conventional tillage system, the furrow turning being an important method for reducing weeds by incorporating the seed in depth and frying and burying the weed roots to the depths, making it difficult to grow, the largest number being determined in 2016, as in the case of other crops, and the lowest in 2015, climatic conditions favoring the growth of weeds.

From the data presented in Tab. 7 it can be observed that the average yields obtained by the three crops (maize, soybean and peas) following the application of conservative tillage systems are close to those recorded in the classical tillage system, the wheat yield is higher in the system of direct sowing than in the classical tillage system, which means that these crops are suitable for cultivation in conservative tillage systems in the Turda area.

The climatic conditions of the crops vegetation period played an important role in determining the yield of all four cultures, the lack of rainfall, from the important plant phases and their uneven distribution, correlated with the high temperatures, meant that in 2015 a lower yield than the average of the three studied years, 
Table 6. Number of weeds $/ \mathrm{m}^{2}$ after maize crop emergence, Turda 2014-2016

\begin{tabular}{|c|c|c|c|c|c|c|c|}
\hline \multirow{4}{*}{$\begin{array}{l}\text { Nr. } \\
\text { crt. }\end{array}$} & \multirow{4}{*}{ Species } & \multicolumn{6}{|c|}{ Tillage system } \\
\hline & & \multicolumn{3}{|c|}{ Classical tillage } & \multicolumn{3}{|c|}{ Minimum tillage } \\
\hline & & \multicolumn{6}{|c|}{ Year } \\
\hline & & 2014 & 2015 & 2016 & 2014 & 2015 & 2016 \\
\hline 1 & Amaranthus retroflexus & - & - & 1 & 1 & - & 2 \\
\hline 2 & Anagallis arvensis* & 1 & - & - & - & 1 & 1 \\
\hline 3 & Cardaria draba & - & - & 1 & 1 & - & 1 \\
\hline 4 & Chenopodium album* & 6 & 3 & 7 & 5 & 4 & 8 \\
\hline 5 & Convolvulus arvensis & - & - & 1 & - & - & 1 \\
\hline 6 & Echinochloa crus-galli* & 4 & 2 & 2 & 5 & 1 & 4 \\
\hline 7 & Hibiscus trionum & - & - & 1 & - & - & 1 \\
\hline 8 & Lathyrus tuberosus & - & 1 & - & - & - & 1 \\
\hline 9 & Matricaria inodora & - & - & 1 & 1 & - & 1 \\
\hline 10 & Polygonum aviculare & 1 & - & - & - & - & 2 \\
\hline 11 & Polygonum convolvulus* & 2 & 1 & 3 & 3 & 2 & 4 \\
\hline 12 & Rubus caesius* & - & 1 & 1 & 1 & 1 & 1 \\
\hline 13 & Setaria glauca* & 5 & 1 & 4 & 4 & 2 & 5 \\
\hline 14 & Silene noctiflora & - & - & 2 & 1 & - & 1 \\
\hline 15 & Veronica persica* & - & 1 & 2 & 1 & 1 & 2 \\
\hline 16 & Viola arvensis* & - & 1 & - & 1 & - & 2 \\
\hline 17 & Xantium strumarium* & 4 & 4 & 9 & 6 & 7 & 10 \\
\hline & Total & 23 & 15 & 35 & 30 & 19 & 47 \\
\hline
\end{tabular}

Table 7. The yields obtained according to the tillage system, Turda 2014-2016

\begin{tabular}{lcccc}
\hline \multirow{2}{*}{ Tillage system } & \multicolumn{4}{c}{ The yield (kg/ha) } \\
\cline { 2 - 5 } & Wheat & Maize & Soybean & Peas \\
\hline $\begin{array}{l}\text { Classical system } \\
\text { (control variant) }\end{array}$ & 5462 & 6186 & 2540 & 3510 \\
\hline Conservative system & 5444 & $6138^{0}$ & $2520^{0}$ & $3458^{0}$ \\
\hline LSD (p 5\%) & 21 & 16 & 12 & 14 \\
\hline LSD (p 1\%) & 53 & 51 & 43 & 65 \\
\hline LSD (p 0.1\%) & 155 & 159 & 106 & 137 \\
\hline
\end{tabular}

with very significant differences for all cultures studied. By comparison, the climatic conditions in 2014 and 2016 were favorable to the good development of the plants, thus influencing the yield, the differences obtained being statistically ensured that they were significantly higher than the average of the three years (Tab. 8).

\section{Conclusions}

Climate conditions have a great influence on the degree of weeding of agricultural crops, in the years when climate conditions are favorable to crops, the emergence and development of weed species is favored. 
Table 8. The yields obtained according to climatic conditions, Turda 2014-2016

\begin{tabular}{lcccc}
\hline \multirow{2}{*}{ The year } & \multicolumn{4}{c}{ The yield (kg/ha) } \\
\cline { 2 - 5 } & Wheat & Maize & Soybean & Peas \\
\hline $\begin{array}{l}\text { Average year (control } \\
\text { variant) }\end{array}$ & 5453 & 6162 & 2530 & 3454 \\
\hline 2014 & $5689^{* * *}$ & $6553^{* * *}$ & $2655^{* * *}$ & $3642^{* * *}$ \\
\hline 2015 & $4753^{000}$ & $4967^{000}$ & $2019^{000}$ & $2780^{000}$ \\
\hline 2016 & $5917^{* * *}$ & $6966^{* * *}$ & $2916^{* * *}$ & $3939^{* * *}$ \\
\hline LSD (p 5\%) & 20 & 16 & 16 & 20 \\
\hline LSD (p 1\%) & 93 & 67 & 76 & 84 \\
\hline LSD (p 0.1\%) & 162 & 151 & 149 & 164 \\
\hline
\end{tabular}

The mode of soil cultivation influences the number of weed species present in agricultural crops, with a higher number of weed species being recorded in the minimum tillage systems than in the classical tillage system in which the basic work is the return of the furrow.

In the wheat crop where the direct sowing system was applied, a smaller number of weeds/ $\mathrm{m}^{2}$ were recorded as soil weed seeds did not find optimum germination conditions.

\section{References}

1. ANOVA (2015). PC program for variant analyses made for completely randomized polifactorial experiences. USAMV Cluj-Napoca, Romania.

2. Bogdan I (2005). Herbologie, Editura Risoprint, ClujNapoca.

3. Bogdan I, Guş P, Rusu T, Pop A, Vâju A, Morar P (2007). Research concerning weed control in maize crop. Cercetări Agronomice în Moldova, 1 (129): 15-21.

4. Cheţan C, Chețan F, Rusu T, Şimon A (2015). Determining Influence on the Cultivation Technology on Weeds and Soybean Production, ProEnvironment 8: 211 - 215.

5. Chețan C, Rusu T, Chețan F, Şimon A (2016). Research regarding the influence of the weed control treatments on production and qualitative indicators of the soybean cultivated in minimum tillage system. Bulletin UASVM, series Agriculture, 73(2): 58-62.

6. Chețan F, Rusu T, Chețan C, Moraru PI. (2016). Influence of soil tillage upon weeds, production and ecconomical efficiency of corn crop, AgroLife Scientific Journal, 5(1): 36-43.

7. Patel MM, Patel AI, Patel IC, Tikka SBS, Henry A, Kumar D, Singh NB (2003). Weed control in cowpea under rain fed conditions. In: Proceedings of the National Symposium on Arid Legumes, for Food Nutrition. Security and promotion of Trade. Advances in Arid Legumes Research. Hisar, India: 203-206.

8. Gruber S, Claupein W (2009). Effect of tillage intensity on weed infestation in organic farming. Soil Till. Res.: 104111.

9. Șimon A, Chețan F (2017). Erbicidarea miriștilor - o măsură necesară pentru reducerea îmburuienării terenurilor agricole, Agricultura Transilvană, Cultura plantelor de câmp, Buletin informative, 27: 95-97.

10. Torresen KS, Skuterud SR, Tandsaether HJ, Hagemo MB (2003). Long-term experiments with reduced tillage in spring cereals. I. Effects on weed flora weed seed bank and grain yield, Crop Protection, 22 (1): 185-200.

11. Turda Meteo Station

12. Woźniak A, Soroka M (2015). Biodiversity of weeds in pea cultivated in various tillage system, Romanian Agricultural Research, 32: 231-237. 